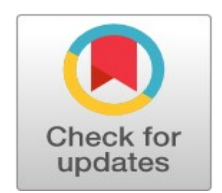

\title{
Financial regulation as moderating, influence of corporate governance, institutional quality, human capital and firm size on financial institutions performance in Kenya
}

\author{
Charles Ndalu Wasike*
}

School of Business, Jomo Kenyatta University of Agriculture and Technology and College of Insurance, Juja, Kenya

\author{
Keywords \\ Financial performance \\ Institutional framework \\ Corporate governance \\ Human capital \\ Firm size
}

Received: 27 September 2017 Accepted: 15 November 2017

Published: 4 December 2017

\begin{abstract}
This paper sheds light on the influence of corporate governance, institutional quality, human capital and firm size on financial institutions performance in Kenya using sampled data from 236 financial institutions during 2010-2015. Further, this research finds out whether the financial regulations could moderate the influence of corporate governance, institutional quality, human capital and firm size on financial institutions performance in Kenya. Stratified sampling was adopted to obtain samples from the heterogeneous financial services sector. Performance indicators used were Return on Investment (ROI) and Return on Equity (ROE) with predictors being human capital, institutional framework, firm size and corporate governance the relationship being moderated by financial regulations. The study established that the four predictors influenced financial institutions performance most of them being statistically significant except firm size. The financial regulation moderation effect was established to be significant in affecting the relationship between financial institutions performance and the predictors.
\end{abstract}

(C) 2017 The Author(s). Published by TAF Publishing.

\section{INTRODUCTION}

The overriding objective of a financial institution is to earn agreeable returns and minimize the risks associated with such returns (Alam, Raza \& Akram, 2011). Returns thus measure the financial performance of a financial institution well. Financial performance measures a firm's usage of assets in generating revenues (Pandey, 2010; Yoo, Lee \& Lee, 2016). The term can also be used in general to measure the financial health of a firm within a given timeframe. Many scholars have employed Return on Asset (ROA) and ROE as proxies of financial performance. However, financial performance indicators may be varied with profitability, liquidity, solvency, financial efficiency and repayment being the widely used ones. Reliance on the financial sector to spur economic growth has seen Kenya deepen her capital markets and work towards development of an international financial centre (Government of Kenya, 2008). Central Bank of Kenya (2015) showed that payment systems in Kenya had grown rapidly overtime largely supported by faster growth of internet and mobile phones, e-commerce, technological developments and Near Field Communication (NFC).

Kenya's financial sector has grown significantly in size and complexity as it continues to support the overall economy. According to Central Bank of Kenya (2015) the sector constitutes banking, capital markets, insurance, pensions, savings credit cooperatives, microfinance institu-

\footnotetext{
* Corresponding author: Charles Ndalu Wasike

†Email: ndaluwasike2006@yahoo.com
} 
tions, money remittances companies, foreign exchange bureaus and development finance institutions with safety nets and resolution institutions such as the Kenya Deposits Insurance Corporation (KDIC) for commercial and microfinance banks; Investor Compensation Fund for Capital Markets subsector; and the Insurance Policyholders' Compensation Fund for the insurance subsector. The institutions' support infrastructure includes Credit Information Sharing (CIS) platforms through Credit Reference Bureaus and Fi- nancial Markets systems of trading, payments and settlements, and custodial services platforms. As a proportion of nominal GDP, the financial sector's total assets excluding capital markets accounted for 83.27 per cent in 2015 while equities' market capitalization was 32.93 per cent. Central Bank of Kenya (2015) indicated that the sector's share of GDP declined compared to 2014, with the largest fall coming from the banking industry in Table 1.

TABLE 1. Share of the financial sector to GDP

\begin{tabular}{lcccccc}
\hline \hline \multirow{2}{*}{ Industry } & \multicolumn{2}{c}{$\mathbf{2 0 1 3}$} & \multicolumn{2}{c}{$\mathbf{2 0 1 4}$} & \multicolumn{2}{c}{$\mathbf{2 0 1 5}$} \\
\cline { 2 - 7 } Indicators & Kshs M & \% of GDP & Kshs M & \% of GDP & Kshs M & \% of GDP \\
\hline Normal GDP & $4,745,439$ & - & $5,3398,020$ & - & $6,224,309$ & - \\
Banking net assets & $2,730,394$ & 56.97 & $3,199,396$ & 59.27 & $3,492,643$ & 56.11 \\
Microfinance net assets & 41,400 & 0.87 & 56,900 & 1.05 & 69,465 & 1.12 \\
Insurance assets & 366,252 & 7.72 & 426,310 & 7.90 & 478,752 & 7.69 \\
Pension industry assets & 696,680 & 14.68 & 788,150 & 14.60 & 814,100 & 13.08 \\
Sacco industry assets & 257,368 & 5.42 & 301,537 & 5.59 & 328,244 & 5.27 \\
Total assets & $4,065,094$ & 85.66 & $4,772,293$ & 88.41 & $5,183,204$ & 83.27 \\
Equity market Cap. & $1,920,718$ & 40.48 & $2,300,054$ & 42.61 & $2,049,539$ & 32.93 \\
\hline \hline
\end{tabular}

The Table 1 shows an upward trend in financial sector's performance and development. The performance and transformation had largely been enabled by financial sector reforms, technological advancement and globalization
(Dianita, 2015, Kamau \& Were, 2013). According to Table 2, Kenya's banking subsector compares well with other regions.

TABLE 2 . Kenya's financial system in comparison to other financial systems

\begin{tabular}{lccc}
\hline \hline Private & Credit/GDP*(\%) & Deposits/GDP*(\%) & Bank Concentration \\
\hline Kenya & 21.7 & 30.9 & 45 \\
Uganda & 13.9 & 26.1 & 81 \\
South Africa & 162.4 & 63.3 & 78.9 \\
Malaysia & 96.4 & 109.4 & 48.5 \\
Germany & 102.2 & 103.6 & 74.4 \\
\hline \hline
\end{tabular}

Like any other place, the financial market in Kenya allocates finance through mobilising surplus funds from those who have and distributing them to those who need to spend more than what they have. In addition institutions function as distributor of economic risk through the creation and distribution of securities.

Many countries have experienced banking problems that have been hampering economic development. This has instigated financial reforms by countries and interna- tional organizations such as World Bank and the International Monetary Fund (Barth, Caprio Jr \& Levine, 2001). Despite posting a general upward trajectory in performance, the financial sector has also witnessed a collapse of many institutions in the past Ten (10) years. This begs the questions what determines the performance of financial institutions in Kenya? This paper examines factors that drive financial institutions performance in Kenya. 


\section{LITERATURE REVIEW}

There have been varied studies on determinants of performance. Berger (1995) showed that the net interest margins of banks had a positive relationship with leverage, the opportunity cost, the risk of default and management efficiency. Burca \& Batrinca (2014) using profitability as a proxy for financial performance found out that the performance of a single financial institution is critical because of the contagion effect to the sector and to the overall growth of the economy.

Epure \& Lafuente (2015) confirmed that appointing CEOs from outside the bank was associated with relatively higher performance, thus affirming the potential benefits of new organizational practices. This reinforces the importance of strategic human resources management in institutional performance. Members of Staff with proven technical expertise helps in the selection and monitoring of projects for funding and also build a good customer relationship that increases performance management (Churchill, 2000; Norell, 2001; Schreiner, 2000). There are various findings that link human capital with higher performance and sustainable competitive advantage (Nordhaug, 1998); higher organizational commitment (Iles, Mabey \& Robertson, 1990) and enhanced organizational retention (Robertson, Iles, Gratton \& Sharpley, 1991). Hence, all this debates fundamentally concludes that human capital has a direct association with financial performance. Other studies done but not in financial sector corroborate the evidence. A causal model by Selvarajan et al. (2007) indicated that human capital development improved innovations and consequently affected positively the firm's performance.

Another important factor cited as important in influencing financial performance is the financial structure. Several studies attest to this positive association between financing choices and firm's performance (Frank \& Goyal, 2004; Ghosh, Nag \& Sirmans, 2000; Shin \& Seo, 2017). Zeitun \& Tian (2007) found out that short-term debt decreases a firm's performance. Other scholars disagree and assert that leverage has a significant negative link with firm's performance measured both in accounting and market terms (Zeitun \& Tian, 2007). Onayemi, Akindapo, Ojokuku, Adegboyega \& Abayomi (2010) suggested that debt ratio had a negative effect on the firm's performance. Omondi \& Muturi (2013) study, suggested that leverage as calculated by ratio of debt-equity, had a negative impact on financial performance. The study also infers that liquidity (current assets over current liabilities) is critical in improving the firm's financial performance.
Firm size influences financial performance. Burca \& Batrinca (2014) study, revealed that there is a positive link between size and financial performance. This results from larger firms more resources, better risk diversification, complex information systems and better expenses management. Omondi \& Muturi (2013) concluded that company size has a positive effect on financial performance. Barako \& Brown (2008) corroborated by establishing that firm (total assets and capitalization) is strongly and positively associated with access to financial services. Pranowo, Achsani, Manurung \& Nuryartono (2010) study used the total assets and firm's age to measure its effect on financial distress.

Financial regulations affect the performance of institutions. Nasieku, Eunic \& Olaroyeke (2014) advocated for looser regulatory policy on minimum capital requirement as measured by leverage ratio while encouraging banks to hold capital levels that add value at risk as proposed base II. Levine (2003) indicated that tighter regulations on bank entry and bank activities boosted the cost of financial intermediation. Brownbridge \& Kirkpatrick (2000) agreed on the effect of financial regulations and even suggested more policy options for the weaker prudential systems. Porta, Lopez-de-Silanes, Shleifer \& Vishny (1998) pointed out the legal rules protecting shareholders and creditors and showed the prevalence of such rules in 49 countries around the world. Further, a cross-country comparison conducted by Williamson \& Mahar (1998) concluded that prudential regulation and supervision were stronger in countries experiencing less severe financial crisis as compared to those experiencing more severe crisis. The research results are also in agreement with proponents that support Micro Finance Institutions (MFI) regulation especially protection of depositors. They argue that regulations are meant to contribute to the stability and public confidence on the financial system (Hardy, Phillips \& Lawrence, 2003; Steel \& Andah, 2003).

Financial performance is dependent on the corporate governance. The running and accountability structures of institutions matter since it is associated with a lower cost of capital, higher returns on equity, greater efficiency, and more favorable treatment of all stakeholders (Claessens, 2006; Johnson, Boone, Breach \& Friedman, 2000) provided a link between investor protection and financial crises. They established unequal treatment of outsider investors by insider investors. They were treated well only as long as future prospects were bright and when interested in continued external financing. In the event of future prospects 
deterioration, the insiders expropriated and left the outside investors, whether shareholders or creditors, without option. The expropriation affected security price negatively especially deep in countries with poor investor protection. Obiero (2002) found out that ineffective board and management malpractices are the major reasons for bank failure. He further noted that although the legal provisions of the banking regulatory framework have comprehensive coverage and adequacy in content to reduce chances of failure, timely intervention by CBK was important if they were to be effective.

According to Kairuthi (2010), Institutional framework in terms of systems and appropriate controls influences the growth of financial institutions in Kenya. His case study of Equity Bank Kenya Ltd revealed that the main factors that influence the growth of financial institutions in Kenya included management, customer convenience, policies and procedures, technology and other factors such as government policies, economic factors, competition in the banking industry, employees and rapid change in technology. Yin \& Qi (2010) study indicated a high consistency between the score of institutional factor and the development level of cooperative organization. It is widely acknowledged that a well-structured banking system, defined by its supervisory practices, risk taking, and governance, promotes greater financial performance and economic stability (Purnamasari \& Fitdiarini, 2016; Vianney, 2013).

La Porta, Lopez-de-Silanes \& Shleifer (2000) studied broadly and acknowledged that common element to the explanations of the large differences among countries in ownership concentration in publicly traded firms, in the breadth and depth of capital markets, in dividend policies, and in the access of firms to external finance was how well investors, both shareholders and creditors, were protected by law from expropriation by the managers and controlling shareholders of firms. They described the differences in laws and the effectiveness of their enforcement across countries, discussed the possible origins of these differences, summarized their consequences, and assessed potential strategies of corporate governance reform. They found that the legal approach is a more fruitful way to understand corporate governance and its reform than the conventional distinction between bank-centered and market-centered financial systems.

Various models have been used to investigate the determinants of financial performance. The seminal work of
Berger \& Hannan (1993) introduced explicit measures of efficiency in the test of SCP. In their study they proposed to test four hypotheses two from market power paradigm that is the established SCP and Relative Market Hypothesis (RMP) and the other two from efficiency paradigm the Xefficiency and scale efficiency hypotheses. The idea was to test whether market structure and efficiency affected performance. Whether efficiency affected concentration or concentration affected efficiency. Scholars like Katib (2004) and Samaad (2008) included measures of concentration and market power in their models. The market power variable was taken as a proxy of efficiency implicitly. However, their studies have been criticized for not including an exclusive measure of efficiency.

More studies Chortareas, Garza-Garcia \& Girardone (2011), Prasad \& Radhe, (2011), Seelanatha (2010) have followed the Berger \& Hannan (1993) methodology by explicitly including the efficiency measures in their estimations. They have also included other control variables such as Gross Domestic Product (GDP), inflation, risk, size and ownership in testing these hypotheses and checking their influence on financial performance.

Competition in banking sector is affected by socioeconomic and structural factors (Gaertner \& Sanya, 2012; Mwega, 2011; Mugume, 2010). Their separate studies investigated empirically bank competition for four countries, Kenya, Uganda, Tanzania and Rwanda. The studies made use of nonstructural measures such as Lerner's index and $P-R, H$ statistic to gauge market contestability. The foregoing indicators of financial performance can be summarized in Table 3 as follows.

TABLE 3 . Indicators of financial performance

\begin{tabular}{|c|c|c|}
\hline Indicator & Sign & Proxy \\
\hline \multirow[t]{3}{*}{ Efficiency } & Positive & Cost X-efficiency \\
\hline & & Profit X-efficiency \\
\hline & & Scale economies \\
\hline \multirow[t]{4}{*}{ Costs } & negative & Scope economies \\
\hline & & Cost to Income Ratio \\
\hline & & Cost Marging \\
\hline & & Total costs/total income \\
\hline \multirow[t]{3}{*}{ Profit } & Positive & Return on capital \\
\hline & & Return on assets \\
\hline & & Net interest margin \\
\hline \multicolumn{3}{|l|}{ Market structure } \\
\hline \multirow[t]{2}{*}{ • Number of FIs } & Positive & Number of banks \\
\hline & & Per capita number of banks \\
\hline - Concentration & Ambivalent & $\mathrm{HH} 1, \mathrm{C} 3, \mathrm{C} 5, \mathrm{C} 10$ \\
\hline
\end{tabular}




\section{METHODOLOGY}

This study provides empirical evidence on the relationship between the performance of financial sector and five independent variables (institutional framework, corporate gov ernance, firm size and human capital). The study assesses the driving determinants of financial sector's performance in Kenya in the years 2010-2015. Financial performance is proxied by ROA and ROE. Corporate gov ernance is proxied by board meetings and total number of independent di- rectors as a ratio of total directors. Human capital is measured by budget on research and development and Training budget as\% of total costs. Firm size is proxied by total assets and capital. Lastly, institutional framework is proxied by standard operating procedures, technology budget and presence of code of conduct. The population was all the financial institutions in Kenya. A total of 236 financial institutions was targeted. The composition of financial institution is as presented in the Table 4.

TABLE 4 . List of licensed financial institutions in Kenya

\begin{tabular}{lcl}
\hline \hline $\begin{array}{l}\text { Type of Financial Institution } \\
\text { Licensed }\end{array}$ & Population & Reference/Source \\
\hline Commerical banks & 43 & Central Bank of Kenya (2014a) \\
Licensed SACCOs (2014) & 135 & SASRA \\
Licensed deposit taking microfinance & 19 & Central Bank of Kenya (2014b) \\
Licensed insurance companies & 49 & Insurance Regulatory Authority (2014) \\
Grand total & 236 & \\
\hline \hline
\end{tabular}

Stratified sampling was adopted since the financial sector has different institutions serving different constituents.
We undertook a three-stage sampling design to obtain the following results in Table 5.

TABLE 5 . Sample size of respondents of FIs

\begin{tabular}{lccc}
\hline \hline Type of Financial Institution & Population & Sample Size & Respondents \\
\hline Licensed commercial banks & 43 & 26 & 26 \\
Licensed SACCOs & 135 & 84 & 84 \\
Licensed deposit taking microfinance & 9 & 6 & 6 \\
Licensed insurance companies & 49 & 30 & 30 \\
Grand total & 236 & 146 & 146 \\
\hline \hline
\end{tabular}

Primary data were collected using questionnaire. The questionnaires were sent to the managers (top managers, finance managers and credit managers) of various financial institutions.

Correlation Analysis, multiple linear regression and Analysis of Variance (ANOVA) were carried out to determine the effects of determinants on financial development in the regression model. Based on the above discussion, a model of financial performance was estimated following the two specifications (1 and 2).

$Y=\beta_{0}+\beta_{1} X_{1}+\beta_{2} X_{2}+\beta_{3} X_{3}+\beta_{4} X_{4}+\varepsilon$

Where:

- $Y$ is the Financial Performance (FP)

- $\beta_{0}$ is the constant.

- $X_{1}$ represents the Institution Framework (IF)
- $X_{2}$ represents the Corporate Governance (CG)

- $X_{3}$ represents the Human Capital (HC)

- $X_{4}$ represents the Firm Size (EG)

- $\epsilon$ is the error term.

where $x_{i}, i=1, \ldots, n$ are known, $\alpha$ and $\beta$ are unknown, and $\epsilon_{i}$ are independent identically normally distributed random errors with expected value 0 and unknown variance $\sigma^{2}$, and $Y_{i}, i=1, \ldots, n$ are observed. The moderating effect was tested using the following interaction model:

$Y=\beta_{0}+\beta_{1} X_{11}+\beta_{2} X_{12}+\beta_{3} X_{13}+\beta_{4} X_{14}+\varepsilon$

and

$Y=\beta_{0}+\beta_{1} X_{1}+\beta_{2} X_{2}+\beta_{3} X_{3}+\beta_{4} X_{4}+Z\left(\beta_{1} X_{1}+\beta_{2} X_{2}+\right.$ $\left.\beta_{3} X_{3}+\beta_{4} X_{4}\right)$ 


\section{ANALYSIS OF RESULTS}

Variance Inflation Factor (VIF) was used to test for multicollinearity in this study. The rule of the thumb is that a VIF of more than 10 indicates presence of multicollinearity (Gu- jarati, 2004). Conversely, Tolerance which is $1 / 10$, indicates that a value equals to or less than 0.1 signals presence of multicollinearity. These results are represented in Table 6 below.

TABLE 6. Multicollinearity results

\begin{tabular}{lcc}
\hline \hline Variable & VIF & Tolerance (1/VIF) \\
\hline Human capital & 1.19 & 0.841964 \\
Institutional framework & 1.15 & 0.870890 \\
Financial regulation & 1.07 & 0.937373 \\
Corporate governance & 1.03 & 0.975098 \\
Firm size & 1.02 & 0.981454 \\
Mean VIF & 1.09 & \\
\hline \hline
\end{tabular}

Table 6 indicates that there was no multicollinearity for all variable constructs as the VIF was less than 10 with accompanying $1 /$ VIF less than 1 . However, firm size showed the lowest multicollinearity followed by corporate governance. To measure reliability we used Cronbach's coefficient alpha to ensure there to check for internal consistency as advised by (Carmines \& Zeller, 1979, Cronbach, 1951). Cronbach's alpha ranges from 0 to 1 which is a measure of reliability. The study minimum test of reliability was based on Cronbach's alpha of 0.70 . The results are presented in the Table 7.

TABLE 7 . Results of reliability test

\begin{tabular}{lccc}
\hline \hline Variable & Number of Items & Cronbach Alpha & Decision \\
\hline Human capital & 5 & 0.950 & Reliable \\
Institutional framework & 2 & 0.914 & Reliable \\
Financial regulation & 4 & 0.491 & Reliable \\
Corporate governance & 3 & 0.669 & Reliable \\
Firm size & 2 & 0.458 & Reliable \\
Financial performance & 5 & 0.629 & Reliable \\
\hline \hline
\end{tabular}

\section{Descriptive Statistics}

Descriptive statistics comprising of means, Coefficient of Variation (CV) standard deviation and percentages were used on the variables; dependent and independent variables.

TABLE 8 . Importance of corporate governance on financial performance

\begin{tabular}{lc}
\hline \hline Importance of Corporate Governance on Performance & Percent (\%) \\
\hline Curbs misappropriation of shareholders funds & 1 \\
Helps run institution & 25 \\
Separation of power & 6 \\
Responsible for strategic planning and decision making & 10 \\
Ensures adequate accountability & 13 \\
Provision of leadership to an institution & 46 \\
\hline \hline
\end{tabular}

From Table 8, it can be deduced that the main importance of corporate governance in an organization according to this study was to provide leadership at forty six percent (46\%). This was followed by the running of the organiza- tion at twenty five percent (25\%). Respondents were further asked to give their opinion on the importance of institutional arrangement on their performance. Table 9 presents the results. 
TABLE 9. Importance of institutional framework in financial performance

\begin{tabular}{lc}
\hline \hline Importance of institutional framework on performance & Percent (\%) \\
\hline Enables maximization of resources (efficiency) & 12 \\
Provides institutional structure (accountability structures) & 50 \\
Makes institution sound and stable & 20 \\
Guides institution on the direction to take & 13 \\
Ensures fair business practices & 5 \\
\hline \hline
\end{tabular}

The main influences of institutional framework on financial development from Table 9, is that it provides accountability structures and makes the institution sound and stable.
Respondents' suggestions on the further measures to be taken to ensure improved performance yielded the following results as shown in Table 8.

TABLE 10. Financial measures that enhance financial performance

\begin{tabular}{lc}
\hline \hline Variable & (Percent \%) \\
\hline Strategic talent acquisition to increase productivity & 12 \\
Risk management like diversification of revenue generation & 8 \\
Firm laws to protect shareholders' rights & 15 \\
Improving accounting systems for efficiency & 10 \\
Use of technology to increase product offerings & 25 \\
Prudent financial management (Good investment mix) & 30 \\
\hline \hline
\end{tabular}

From Table 10 prudent financial management, use of technology and firm laws to protect shareholders were identified as major determinants of financial performance. Further, talent acquisition, risk management and accounting systems were least seen to affect performance.

On firm's size, the researcher investigated the significance of firm's size (in terms of capital and total assets) to the institutional performance. The probing question helped determine whether the sizes of financial institutions af- fected performance. The Table 11 below presents findings. From the Table 11, there was no consensus on the significance of firm's size. The means, and standard deviations with high coefficient of variations pointed to disagreement on the importance of firm's size to performance.

From the Table 12, there was general consensus that human capital matter. The means, standard deviations with small coefficient of variations pointed to agreement on the importance of human capital to performance.

TABLE 11. Descriptive statistics for firm's size

\begin{tabular}{lcccc}
\hline \hline Variable & $\boldsymbol{N}$ & Mean & Standard Deviation & Coefficient of Variation \\
\hline $\begin{array}{l}\text { Did the size of institution in } \\
\text { total assets affect performance }\end{array}$ & 109 & 3.45 & 0.89 & 0.76 \\
\begin{tabular}{l} 
Did capital contribute to performance \\
\hline \hline
\end{tabular} & 109 & 3.96 & 1.07 & 0.87 \\
\hline
\end{tabular}


TABLE 12 . Descriptive statistics for human capital

\begin{tabular}{lcccc}
\hline \hline Variable & $\boldsymbol{N}$ & Mean & Standard Deviation & Coefficient of Variation \\
\hline $\begin{array}{l}\text { Presence of institution training policy } \\
\text { (affect performance) }\end{array}$ & 109 & 4.32 & 0.58 & 0.20 \\
$\begin{array}{l}\text { Institutional supports for the staff training } \\
\text { (affect performance) }\end{array}$ & 109 & 4.33 & 0.67 & 0.18 \\
$\begin{array}{l}\text { Institution budget on research } \\
\text { and development(affect performance) }\end{array}$ & 109 & 4.05 & 0.50 & 0.25 \\
$\begin{array}{l}\text { Institution employment of professional } \\
\text { (affect performance) }\end{array}$ & 109 & 4.35 & 0.46 & 0.18 \\
$\begin{array}{l}\text { The trained staff link to institution } \\
\text { productivity and performance(affect performance) }\end{array}$ & 109 & 4.37 & 0.37 & 0.18 \\
\hline
\end{tabular}

\section{Correlation Results}

The Pearson $r$ statistic for bivariate correlations results are shown in Table 13. From Table 13, most variables had less than 0.3 showing no correlation with the corporate governance against institutional framework that showed a weak correlation of 0.301 .

TABLE 13 . Correlations of variables

\begin{tabular}{lcccccc}
\hline \hline & $\begin{array}{c}\text { Financial } \\
\text { Performance }\end{array}$ & $\begin{array}{c}\text { Financial } \\
\text { Regulation }\end{array}$ & $\begin{array}{c}\text { Corporate } \\
\text { Governance }\end{array}$ & $\begin{array}{c}\text { Institutional } \\
\text { Framework }\end{array}$ & $\begin{array}{c}\text { Firm } \\
\text { Size }\end{array}$ & $\begin{array}{c}\text { Human } \\
\text { Capital }\end{array}$ \\
\hline Financial performance & 1 & & & & & \\
Financial regulation & .042 & 1 & & & & \\
Corporate governance & .031 & .115 & 1 & & & \\
Institutional framework & .057 & -.028 & .301 & 1 & & \\
Firm size & .059 & -.013 & .092 & -.097 & 1 \\
Human capital & .028 & .020 & -.028 & .0340 & -.068 & 1 \\
\hline \hline
\end{tabular}

\section{Regression Analysis}

The research conducted a regression analysis on all independent variables (corporate governance, institutional framework, human capital and firm's size) with the dependent variables (financial performance) to establish the re- lationship as well as the causality and its direction which becomes an overall model. Table 14 presents the overall regression results without the influence of the moderator (financial regulations).

TABLE 14 . Regression results of overall model

\begin{tabular}{lccccc}
\hline \hline Model & \multicolumn{4}{c}{ Unstandardized Coefficients } & \multicolumn{3}{c}{ Standardized Coefficients } \\
\hline & $\boldsymbol{B}$ & Standard Error & $\mathbf{B}$ & $\boldsymbol{t}$ & Significance \\
\hline Corporate governance & 0.677 & 0.127 & 0.346 & 5.311 & 0.000 \\
Institutional framework & 0.278 & 0.064 & 0.416 & 4.361 & 0.000 \\
Human capital & 0.411 & 0.187 & 0.146 & 2.195 & 0.030 \\
Firm size & 0.069 & 0.070 & 0.088 & 0.983 & 0.328 \\
\hline \hline
\end{tabular}

The regression result presented in Table 14 indicates that all variables have a positive impact on financial development. The regression equation above has established that taking independent variables to be constant financial performance will be 2.614. A unit increase in corporate gov- ernance, institutional framework, human capital and firm's size increases financial development by 0.346 units, 0.416 units 0.146 units and 0.088 units respectively. The coefficients are used to answer the following regression model which relates the predictors (independent) and dependent 
variables. Most of the variables are significant at 95\% apart from firm's size which is not significant at that level.

The analysis of variance (ANOVA) on the effects of Fi- nancial Development was done to test statistically if the means were significantly different between these groups.

TABLE 15. ANOVA of Financial performance versus independent variable

\begin{tabular}{lccccc}
\hline \hline Model & Sum of Square & $\boldsymbol{d} \boldsymbol{f}$ & Mean Squares & $\boldsymbol{F}$ & Sig. \\
\hline Regression & 7855.694 & 4 & 1963.9 & 289.523 & .000 \\
Residual & 712.247 & 105 & 6.783 & & \\
Total & 8567.941 & 109 & & & \\
\hline \hline
\end{tabular}

Result from Table 15 revealed that financial performance with independent variables has $F$ statistic of 289.5 and the $p$-value is 0.000 . The $p$-value of 0.000 is within the set level of significance of 0.05 . This result indicates that the overall regression model was statistically signifi- cant and useful for prediction purposes at $5 \%$ significance level. This further indicates that the independent variables used (corporate governance, institutional framework, firm size and human capital) are statistically significant in predicting financial performance of financial institutions.

TABLE 16. Model summary

\begin{tabular}{lccccc}
\hline \hline Model & $\boldsymbol{R}$ & $\boldsymbol{R}$ Square & $\begin{array}{c}\text { Adjusted } \\
\boldsymbol{R} \text { Square }\end{array}$ & $\begin{array}{c}\text { Std Error of the } \\
\text { Estimate }\end{array}$ & Durbin-Watson \\
\hline 1 & 0.958 & 0.917 & 0.914 & $2.6045 \mathrm{E} 0$ & 1.819 \\
\hline \hline
\end{tabular}

Model summary in Table 16 shows the output for model fitness and the value of adjusted $R$ squared was 0.917 . This shows that the variables (Corporate Governance, Institutional Framework, Firm's Size and Human Capital) tested explains $91.7 \%$ on the financial performance in Kenya at 95\% confidence interval. $R$ is the correlation coefficient which shows the relationship between the study variables. From the findings shown in the Table 12 there was a strong positive relationship between the study variables as shown by 0.958 . The five independent variables that were studied, explain only $91.70 \%$ of these four determinants of financial development in Kenya as represented by the adjusted R-Squared. Thus the overall model assumes the following. $Y=\beta_{0}+\beta_{1} X_{1}+\beta_{2} X_{2}+\beta_{3} X_{3}+\beta_{4} X_{4}+\varepsilon$ became: $Y=0.346$ Corporate Governance +0.416 Institutional
Framework + 0.146 Human Capital + 0.088 Firm Size.

However, since the model with the moderation better explained the relationship, the second model was taken to represent the relationship. The established moderation regression equation was:

$Y=\beta_{0}+\beta_{1} X_{1}+\beta_{2} X_{2}+\beta_{3} X_{3}+\beta_{4} X_{4}+Z\left(\beta_{1} X_{1}+\beta_{2} X_{2}+\right.$ $\left.\beta_{3} X_{3}+\beta_{4} X_{4}\right)$

Where

$Z$ is the moderating variable.

In testing the moderating effect of financial regulation, the researcher used the equation 5 and obtained the following regression model which explained $91.8 \%$ of financial performance as shown in Table 13.

The ANOVA Table 14 below shows that the model is significant at $95 \%$ level of confidence with a mean square of 983.589 for regression and $F$ statistic of 142.075 .

TABLE 17. Moderated model summary

\begin{tabular}{ccccc}
\hline \hline Model & $\boldsymbol{R}$ & $\boldsymbol{R}$ Square & Adjusted $\boldsymbol{R}$ Square & Standard Error of the Estimate \\
\hline & 0.958 & 0.918 & 0.912 & 2.63116 \\
\hline \hline
\end{tabular}

TABLE 18. ANOVA for moderated model

\begin{tabular}{cccccc}
\hline \hline Model & Sum Squares & $\boldsymbol{d} \boldsymbol{f}$ & Mean Square & $\boldsymbol{F}$ & Significance \\
\hline 7868.715 & 8 & 983.589 & 142.075 & 0.000 \\
0.069 & 0.070 & 0.088 & 0.983 & 0.328 \\
\hline
\end{tabular}


TABLE 19. Regression results for moderated model

\begin{tabular}{lccccc}
\hline \hline \multirow{2}{*}{ Model } & \multicolumn{4}{c}{ Unstandardized Coefficients } & \multicolumn{2}{c}{ Standardized Coefficients } \\
\cline { 2 - 6 } & $\boldsymbol{B}$ & Standard Error & $\boldsymbol{B}$ & $\boldsymbol{t}$ & Significance \\
\hline Corporate governance & 0.037 & 0.567 & 0.283 & 0.975 & 0.033 \\
Institutional framework & 0.022 & 0.275 & 0.194 & 0.471 & 0.040 \\
Human capital & 0.0318 & 0.318 & 0.229 & 0.100 & 0.050 \\
Firm size & 0.0762 & 0.829 & 0.423 & 0.920 & 0.046 \\
Corp. governance * FR & 0.01104 & 0.069 & 0.063 & 0.016 & 0.008 \\
Institutional framework *FR & 0.00248 & 0.031 & 0.227 & 0.080 & 0.040 \\
Firm size * FR & 0.00921 & 0.098 & 0.295 & 0.094 & 0.047 \\
Human capital *FR & 0.00259 & 0.035 & 0.133 & 0.074 & 0.037 \\
\hline \hline
\end{tabular}

The moderating effect is present if and only if betas are statistically significant. From the Table 18 betas $\left(\beta_{s}\right)$ were statistically significant within a confidence interval of 95\%. The moderated regression becomes $Y=$ $\beta_{0}+\beta_{1} X_{1}++\beta_{2} X_{5}+Z \beta_{3} X_{1}+\varepsilon$ becomes. In the Table $15 \mathrm{FR}$ represents financial regulation which is a moderator. From the table 15, equation.

$Y=\beta_{0}+\beta_{1} X_{1}+\beta_{2} X_{2}+\beta_{3} X_{3}+\beta_{4} X_{4}+Z\left(\beta_{1} X_{1}+\beta_{2} X_{2}+\right.$ $\beta_{3} X_{3}+\beta_{4} X_{4}$ ) becomes

$Y=0.283 C G+0.19 I F+0.229 H C+0.43 F S+$ $0.063 C G F R+0.227 I F F R+0.295 F S F R+0.133 H C F R$

\section{CONCLUSION}

The study revealed that there were great variations in the financial development of financial institutions due to changes in corporate governance, institutional framework, firm's size and human capital. This is an indication that corporate governance, institutional framework and human capital had great effects on the financial performance of financial institutions.

Institutional quality was key for providing accountability structures, ensuring stability and guiding institutions. These results agree with Obiero (2002) who found that ineffective board and management malpractices are the major reasons for bank failure. Other scholars like Yin \& Qi (2010) found institutional framework in terms of appropriate systems and control matters.

The moderation effect of financial regulation was too found to be statistically significant. Obiero (2002) confirmed the importance of regulation by affirming that the legal provisions of the banking regulatory framework are adequate in reducing probability of failure. The research results are also in agreement with proponents that support MFI regulation especially protection of depositors. They argued that the regulations are meant to contribute to the sta bility and public confidence in the financial system. (Hardy et al., 2003; Steel \& Andah, 2003).

However, firm's size though from model showed a relationship with performance, was not statistically significant in determining that performance. Statistically owners' capital and firm assets proxies of firm's size did not significantly lead to financial performance. The results indicate that firm's size is not a critical factor of profitability in the sector as more small institutions can develop and as such a public policy to increase capitalization may not necessarily or minimally impact stability and growth in financial institutions. This study disagrees with the findings of Burca \& Batrinca (2014), Omondi \& Muturi (2013) and Barako \& Brown (2008) who found that firm's size substantially affected financial institutions performance due to economies of scale and scope.

From the study human capital enhancement by institutions was achieved through training policy, institutional support for staff training, budgetary allocation on research and development, and employment of professional which consequently showed a link between training and productivity and performance. This agrees with other studies that posited that human capital affects performance since personnel are involved in selection of profitable projects to fund and in the running of the institutions (Burca \& Ba trinca, 2014; Omondi \& Muturi, 2013 and Barako \& Brown, 2008).

Corporate governance was cited as critical in providing leadership, running of institutions and ensuring accountability. This confirmed Claessens (2006) study results that indicated that good corporate governance generally paysfor firms, for markets, and for countries. It is associated with a lower cost of capital, higher returns on equity, greater efficiency, and more favorable treatment of all stakeholders, although the direction of causality is not 
always clear. Given the benefits of good corporate gover nance, firms and countries should voluntarily reform more. Further, the study determined other factors that determined financial institutions' performance. These included prudent financial management in terms of investment mix considered the most critical, followed by use of technology, firm's laws to protect shareholders, accounting systems to improve efficiency, strategic talent acquisition and risk management through revenue stream diversification in that order.

\section{REFERENCES}

Alam, H.M., Raza, A., \& Akram, M. 2011. Financial performance of leasing sector: The case of Pakistan. Interdisciplinary Journal of Contemporary Research in Business, 2(12): 339-345.

Barako, D.G., \& Brown, A.M. 2008. Corporate social reporting and board representation: Evidence from the Kenyan banking sector. Journal of Management \& Governance, 12(4): 309-324. D0I: 10.1007/s10997-008-9053-X

Barth, J.R., Caprio Jr, G., \& Levine, R. 2001. Banking systems around the globe: Do regulation and ownership affect perfor- mance and stability? In Mishkin, F.S. (Ed.), Prudential supervision: What works and what doesn't. Chicago, IL: Uni- versity of Chicago Press.

Berger, A.N. 1995. The profit-structure relationship in banking--tests of market-power and efficient-structure hypotheses.

Journal of Money, Credit and Banking, 27(2): 404-431. DOI: 10.2307/2077876

Berger, A.N., \& Hannan, T.H. 1993. Using efficiency measures to distinguish among alternative explanations of the structure-performance relationship in banking. Working paper no. 93-118, Board of Governors of the Federal Re- serve System, Washington, DC: WA

Brownbridge, M., \& Kirkpatrick, C. 2000. Financial regulation in developing countries. The Journal of Development Studies, $\quad 37(1): 1-24$. DOI: $10.1080 / 713600056$

Burca, A.M., \& Batrinca, G. 2014. The determinants of financial performance in the Romanian insurance market. Interna- tional Journal of Academic Research in Accounting, Finance and Management Sciences, 4(1): 299-308.

DOI: /10.6007/ijarafms/v4-i1/637

Carmines, E.G., \& Zeller, R.A. 1979. Reliability and Validity Assessment. Quantitative Applications in the Social Sciences. Beverly Hills, CA: Sage Publications.

Central Bank of Kenya. 2014a. Annual bank supervision report. URL: goo.gl/yj6vhu. Last accessed on 17 October 2017. Central Bank of Kenya. 2014b. A list of commercial banks in Kenya. URL: goo.gl/kAQ79T. Last accessed on 21 May 2016. Central Bank of Kenya. 2015. Financial sector stability report. URL: goo.gl/Yp7iAr. Last accessed on 19 March 2016. Chortareas, G.E., Garza-Garcia, J.G., \& Girardone, C. 2011. Banking sector performance in Latin America: Market power ver- $\quad$ sus efficiency. Review of Development Economics, 15(2): 307-325. DOI: 10.1111/j.1467-9361.2011.00610.x

Churchill, G. 2000. Banking on customer loyalty. Journal of Micro-Finance, 2(2): 1-21.

Claessens, S. 2006. Corporate governance and fevelopment. World Bank Research Observer, 21(1): 91-122.

DOI: $10.1093 /$ wbro/lkj004

Cronbach, L.J. 1951. Coefficient alpha and the internal structure of tests. Psychometrika, 16(3): 297-334.

DOI: $10.1007 / \mathrm{bf02310555}$

Dianita, M. 2015. Role of the internal auditor influence and good corporate governance in banking financial performance against state owned corporation. International Journal of Business and Administrative Studies, 1(4): 176-179.

DOI: $10.20469 /$ ijbas.10006-4

Epure, M., \& Lafuente, E. 2015. Monitoring bank performance in the presence of risk. Journal of Productivity Analysis, 44(3): 265-281. DOI: $10.1007 / \mathrm{s} 11123-014-0413-\mathrm{z}$

Frank, M.Z., \& Goyal, V.K. 2004. The effect of market conditions on capital structure adjustment. Finance Research Letters, 1(1): 47-55. DOI: 10.1016/s1544-6123(03)00005-9

Gaertner, M., \& Sanya, S. 2012. Assessing bank competition within the East African community. Working paper no. 12-23, Center for College and Career Success International Monetary Fund. Washington, D.C: WA.

Ghosh, C., Nag, R., \& Sirmans, C.F. 2000. The pricing of seasoned equity offerings: Evidence from REITs. Real Estate Eco- $\quad$ nomics, 28(3): 363-384. DOI: 10.1111/1540-6229.00805 
Government of Kenya. 2008. Kenya vision 2030: First medium term plan (2008-2012). URL: goo.gl/qxxZ6L.

Last accessed on 18 July 2017.

Gujarati, N. 2004. Basic econometrics. New York, NY: McGraw Hill Companies.

Hardy, C., Phillips, N., \& Lawrence, T.B. 2003. Resources, knowledge and influence: The organizational effects of interorga- nizational collaboration. Journal of Management Studies, 40(2): 321-347. DOI: 10.1111/1467-6486.00342

Iles, P., Mabey, C., \& Robertson, I. 1990. Human Resource Managment (HRM) practices and employee commitment: Possi-

ities, pitfalls and paradoxes. British Journal of Management, 1(3): 147-157.

DOI: $10.1111 /$ j.1467-8551.1990.tb00003.x

Insurance Regulatory Authority. 2014. A list of licensed insurance companies in Kenya. URL: goo.gl/VWP7nj. Last ac- $\quad$ cessed on 21 July 2017.

Johnson, S., Boone, P., Breach, A., \& Friedman, E. 2000. Corporate governance in the Asian financial crisis. Journal of Finan- $\quad$ cial Economics, 58(1): 141-186. DOI: 10.1016/s0304-405x(00)00069-6

Kairuthi, L. 2010. Factors influencing the growth of financial institutions in Kenya: A case study of equity bank Ltd. Unpublished doctoral dissertation, University of Nairobi, Nairobi, Kenya.

Kamau, A., \& Were, M. 2013. What drives banking sector performance in Kenya? Global Business and Economics Research

Journal, 2(4): 45-59.

Katib, M.N. 2004. Market structure and performance in the Malaysian banking industry: A robust estimation. Paper

presented in $8^{\text {th }}$ Capital Markets Conference, Indian Institute of Capital Markets, Navi Mumbai, India.

La Porta, R., Lopez-de-Silanes, F., \& Shleifer, A. 2002. Government ownership of banks. The Journal of Finance, 57(1):

265- 301. DOI: 10.1111/1540-6261.00422

Levine, R. 2003. Finance and growth: Theory and evidence. In P. Aghion \& S.N. Durlauf (Eds.), Handbook of economic growth, North Holland, Netherlands: Elsevier.

Mugume, A. 2010. Competition and performance in Uganda's banking system. URL: goo.gl/62msoH. Last accessed on 21

May 2017.

Mwega, F. 2011. The competitiveness and efficiency of the financial services sector in africa: A case study of kenya. African

Development Review, 23(1): 44-59. DOI: 10.1111/j.1467-8268.2010.00271.x

Nasieku, T., Eunice, M.O., \& Olaroyeke, R.T. 2014. Corporate governance and firm earnings quality. Economic and Finance

Review, 2(12): 1-10.

Nordhaug, 0.1998. Competence specificities in organizations: A classificatory framework. International Studies of Man-

ment \& Organization, 28(1): 8-29. DOI: 10.1080/00208825.1998.11656725

Norell, N. 2001. How to reduce arrears in microfinance institutions. Journal of Microfinance/ESR Review, 3(1): 8-20.

Obiero, D. 2002. The banking sector regulatory framework in Kenya: Its adequacy in bank failures. Unpublished doc- toral dissertation, University of Nairobi, Nairobi, Kenya.

Omondi, M.M., \& Muturi, W. 2013. Factors affecting the financial performance of listed companies at the Nairobi securities exchange in Kenya. Research Journal of Finance and Accounting, 4(15): 99-105.

Onayemi, M., Akindapo, A., Ojokuku, R., Adegboyega, A.I., \& Abayomi, A. 2010. Capital structure and firm performance: Evi- $\quad$ dence from Nigeria. European Journal of Economics, Finance and Administrative Sciences, 10: 7-18.

Pandey, I.M 2010. Financial management. New Delhi, India: Vikas publishing House Pvt Ltd.

Porta, R.L., Lopez-de-Silanes, F., Shleifer, A., \& Vishny, R.W. 1998. Law and finance. Journal of Political Economy, 106(6):

1113-1155. DOI: $0.1086 / 250042$

Pranowo, K., Achsani, N.A., Manurung, A.H., \& Nuryartono, N. 2010. Determinant of corporate financial distress in an emerg- ing market economy: Empirical evidence from the Indonesian stock exchange 2004-2008. International Research Jour- nal of Finance and Economics, 52(1): 81-90.

Prasad, G.D., \& Radhe, S.P. 2011. Structure-performance relationship in Nepalese banking industry. Paper presented in International Conference on Economics, Business and Management, Manila, Philippines.

Purnamasari, K., \& Fitdiarini, N. 2016. Corporate diversification and cash holding. Journal of Administrative and Business

Studies, 1(1): 21-27. DOI: 10.20474/jabs-1.1.4 
Robertson, I.T., Iles, P.A., Gratton, L., \& Sharpley, D. 1991. The psychological impact of selection procedures on candidates. Human Relations, 44(9): 963-82. DOI: 10.1177/001872679104400904

Samad, A. 2008. Market structure, conduct and performance: Evidence from the Bangladesh banking industry. Journal of

Asian Economics, 19(2): 181-193. DOI: 10.1016/j.asieco.2007.12.007

Schreiner, M. 2000. Credit scoring for microfinance: Can it work? Journal of Microfinance/ESR Review, 2(2): 105-117.

Seelanatha, L. 2010. Market structure, efficiency and performance of banking industry in Sri Lanka. Banks and Bank Sys- tems, 5(1): 20-31.

Selvarajan, T.T., Ramamoorthy, N., Flood, P.C., Guthrie, J.P., MacCurtain, S., \& Liu, W. 2007. The role of human capital phi- $\quad$ losophy in promoting firm innovativeness and performance: Test of a causal model. The International Journal of Hu- man Resource Management, 18(8): 1456-1470. D0I: 10.1080/09585190701502588

Shin, S.J., \& Seo, W. 2017. Identifying new technology areas based on firm's internal capabilities. Journal of Administrative and Business Studies, 3(3): 114-121. DOI: 10.20474/jabs-3.3.1

World Bank. 2009. The world bank annual report 2009. URL: goo.gl/u97QHx. Last accessed on 12 December 2017.

Steel, W.F., \& Oneida, D.0. 2003. Rural and micro finance regulation in Ghana: Implications for development and per- formance of the industry Africa region. Working paper no. 49, World Bank, Washington, DC: WA.

Vianney, K.J.M. 2013. The Relationship between regulation and financial performance in Rwanda commercial banks.

Unpublished doctoral dissertation, University of Nairobi, Kenya.

Williamson, J., \& Mahar, M. 1998. A survey of financial liberalization. Working paper no. 211, Department of International

Economics, Princeton University, Princeton, NJ.

Yin, L., \& Qi, Y. 2010. Institutional factors affecting the economic performance of Peasant Special Cooperative Organization:

A case of Cuiping District, Yibin City, China. Asian Agricultural Research, 2(2): 23-29.

Yoo, J., Lee, M.K., \& Lee, W.S. 2016. Asymmetrical corporate responses to economic information: Applying the firm size ef- fect. Journal of Administrative and Business Studies, 2(1): 29-34. D0I: 10.20474/jabs-2.1.4

Zeitun, R. \& Tian, G. 2007. Capital structure and corporate performance: Evidence from Jordan. Australasian Accounting

Business and Finance Journal, 1(4): 40-61. D0I: 10.2139/ssrn.2496174

— This article does not have any appendix. - 